\title{
Pemetaan pola permukiman masyarakat di Kecamatan Klungkung: analisa pola dan karakteristik permukiman
}

\author{
Naniek Kohdrata ${ }^{1 *}$, Ni Wayan Febriana Utami ${ }^{1}$, Cokorda Gede Alit Semarajaya ${ }^{1}$ \\ 1. Program Studi Arsitektur Pertamanan, Fakultas Pertanian, Universitas Udayana, Indonesia 80232 \\ *E-mail: naniek_kohdrata@unud.ac.id
}

\begin{abstract}
Abstrak
Mapping of Klungkung sub-district settlement pattern: analysis of settlement pattern and characteristic. The research on Klungkung subdistrict settlement pattern aims to see whether the pattern is following "traditional" residential pattern theory or else. The pattern of community settlements can be used as an indicator of social dynamics as well as social problems. Similarly, it can be an indication of development potential or just the opposite for a development, whether from economic, social, cultural, even political. This study is limited only to find early indications of settlement patterns and residential characteristics. The method used is descriptive qualitative by utilizing GIS software to map residential locations obtained from key respondents and public respondents. The results show that the distribution of growing settlements patterns from core towards outside is the characteristics of the population based on religion or belief. While the pattern of settlements based on the character of the profession/work shows an orbital form, like the planets that surround the sun. Ethnic or race character does not show any particular pattern. This research is a preliminary study on the pattern of settlements in the era of globalization and development of Semarapura city in Klungkung regency. There is a tendency that the settlement pattern is not centered oriented anymore.

Keywords: settlement pattern, landscape of settlement, traditional settlement
\end{abstract}

\section{Pendahuluan}

Kota merupakan salah satu bentuk ruang tinggal manusia. Umumnya manusia akan tinggal berdekatan atau berkelompok dengan manusia lain yang memiliki kesamaan. Beberapa kriteria yang umum dipakai sebagai dasar mengelompok diantaranya adalah kesamaan etnis atau suku, asal-usul, profesi/pekerjaan, latar belakang sosial, dan pada beberapa kasus adalah kepercayaan/keyakinan. Pada masa lalu preferensi dan pilihan manusia bertempat tinggal mencerminkan upaya mengelompokkan diri dengan manusia lain. Kelompok-kelompok hunian yang dibentuk oleh manusia ini kemudian berkembang menjadi komunitas masyarakat dengan ciri-ciri tertentu yang menjadi "tanda" umum dari komunitas tersebut. Sehingga muncullah pada masa dahulu ada yang disebut kampung pecinan, kampong arab, kampung melayu, banjar pande, kampung pabean, dan lain sebagainya. Nama-nama tersebut diberikan karena ciri-ciri atau karakter penduduk yang tinggal di tempat tersebut, baik karena jenis pekerjaan yang sama, etnis atau suku yang sama, atau asal usul yang sama. Cukup jamak di Indonesia masih dapat ditemui nama-nama tempat dengan membawa sejarah historis bekas komunitas hunian sekelompok manusia yang memiliki ciri-ciri/karakter yang sama.

Kota pada masa ini dihuni oleh berbagai macam manusia dengan tingkat latar belakang kehidupan yang jauh lebih kompleks. Undang-Undang Republik Indonesia Nomor 1 Tahun 2011 tentang Perumahan dan Kawasan Permukiman mendefinisikan permukiman sebagai bagian dari lingkungan hunian yang terdiri atas lebih dari satu satuan perumahan yang mempunyai prasarana, sarana, utilitas umum, serta mempunyai penunjang kegiatan fungsi lain di kawasan perkotaan dan kawasan perdesaan. Wacana yang berkembang dalam era globalisasi ini adalah multikultural. Fenomena multiklultural terutama memiliki dampaknya yang lebih nyata dalam konteks perkotaan. Umumnya kota memiliki segala macam fasilitas pendidikan, kesehatan, perdaganagan, hiburan, dan transportasi yang menarik bagi pendatang. Akibatnya adalah beragam manusia akan tinggal dan berpartisipasi dalam kehidupan di kota.

Penelitian di kecamatan Klungkung ini bermaksud untuk melihat apakah terdapat pola tertentu yang terjadi di wilayah penelitian serta karakteristik pemukiman yang mungkin muncul dari pemukiman yang terpetakan. Pola pemukiman masyarakat dapat dipakai sebagai indikator dinamika sosial dan juga 
permasalahan sosial. Demikian pula pola pemukiman dapat menjadi indikasi potensi pembangunan atau justru sebaliknya kendala bagi suatu pembangunan, baik dari aspek ekonomi, sosial, budaya, bahkan politik.

\section{Metode Penelitian}

Penelitian melalui tiga tahapan proses, yaitu inventarisasi data, pengolahan dan analisa data, serta tahap terakhir adalah sintesa. Tahapan pengumpulan data menggunakan sumber-sumber data primer maupun sekunder. Teknik yang pengumpulan data primer dilakukan melalui observasi dan wawancara. Sementara data sekunder didapatkan dari studi pustaka berupa dokumen-dokumen mengenai demografi penduduk kecamatan Klungkung. Variabel yang dipergunakan untuk memetakan kelompok-kelompok pemukiman adalah etnisitas atau suku, religi(agama), dan pekerjaan (ekonomi). Sumber data mempergunakan rujukan Klungkung Dalam Angka Tahun 2016 dan juga partisipan masyarakat.

Penelitian ini ingin mengetahui apakah terdapat identifikasi permukiman penduduk berdasarkan karakter sosial. Karakter-karakter sosial permukiman yang dicari akan menggunakan pendekatan agama, etnisitas, dan pekerjaan sebagai elemen pengidentifikasi. Pemetaan dihasilkan dari data yang menggunakan rujukan sumber Klungkung dalam Angka 2016 dan yang berasal dari mental map responden. Pola permukiman dan karakteristiknya dianalisa dengan deskriptif untuk memaknai pola grafis yang dihasilkan.

Data yang diperoleh dari mental map responden dan data Klungkung dalam Angka (KDA) 2016 diterjemahkan secara spasial dengan menggunakan software GIS. Lokasi variabel dipetakan menurut lokasi yang dipilih responden dan juga berdasarkan data yang diperoleh dari KDA 2016. Hasil penterjemahan data ke bentuk spasial ini kemudian diinterpretasikan secara deskriptif untuk melihat fnomena yang terjadi.

\section{Hasil Dan Pembahasan}

\subsection{Kondisi Umum Wilayah Administrasi Kecamatan Klungkung}

Kecamatan Klungkung merupakan bagian wilayah Kabupaten Klungkung yang terletak di daratan yang menyatu dengan pulau Bali. Data Desa dan Kelurahan dari laman pemerintah Kabupaten Klungkung menunjukkan bahwa luas wilayah administrasi kecamatan Klungkung adalah 29,05 km². Kecamatan Klungkung berbatasan dengan Kabupaten Karangasem di bagian utara, Selat Badung di sisi selatan, dan diapit oleh Kecamatan Dawan di sisi timur serta Kecamatan Banjarangkan di sebelah barat. Wilayah administrasi Kecamatan Klungkung terdiri dari 12 Desa dan 6 Kelurahan.

Kecamatan Klungkung, selain memiliki sistem administrasi yang diatur menurut UU Pemerintah Indonesia, juga masih mempunyai sistem organisasi administrasi secara adat yang diikat melalui keberadaan Desa Adat sebanyak 22 yang langsung menangani 60 Banjar Adat. Desa adat sejumlah 22 desa adat tersebut tersebar di 12 desa dinas dan 6 kelurahan yang ada di Kecamatan Klungkung dalam pembagian yang tidak selalu paralel dengan pembagian administrasi negara.

\subsection{Kependudukan}

Populasi penduduk di Kecamatan Klungkung dari data dalam Klungkung Dalam Angka (KDA) 2016 adalah sebesar 57.360 jiwa. Sex rasio adalah 96,5 yang diperoleh dari jumlah penduduk laki-laki sebanyak 28.170 jiwa dan perempuan sejumlah 29.190 jiwa. Penduduk dengan jumlah terbanyak berada di Kelurahan Semarapura Klod Kangin sebanyak 5.498 jiwa. Sementara Desa Kampung Gelgel memiliki penduduk dengan populasi terkecil, yaitu 999 jiwa, namun dengan tingkat kepadatan tertinggi, yaitu sebesar 14.271 jiwa/km². Desa Selisihan merupakan desa dengan kepadatan penduduk terendah, yaitu 600 jiwa/km².

\subsection{Agama dan Kepercayaan}

Komposisi penduduk beragama berdasarkan data administrasi catatan kependudukan dalam KDA 2016 adalah 89,8\% Hindhu, 8,3\% Islam, 1,4\% Budha, 0,4\% Protestan, 0,1\% Katolik, dan 0,02\% Konghucu. Sementara jumlah tempat peribadatan yang tercatat dalam KDA 2016 adalah 114 pura, 4 gereja, dan 7 mesjid/langgar/mushola, dan 1 klenteng. Hampir 90\% penduduk Kecamatan Klungkung adalah beragama Hindu sehingga dapat digambarkan karakter penduduk dari aspek agama yang relatif homogen. Hal menarik yang dapat dicermati dari karakter kependudukan dalam hal agama dianut adalah adanya peningkatan pemeluk agama Islam sebesar 74\% dari data sensus tahun 2012 ke tahun 2013 (KDA 2015). Peningkatan yang cukup signifikan ini memunculkan dugaan beberapa faktor penyebabnya, yaitu 1) kelahiran dalam keluarga penduduk, 2) konversi agama, 3) penambahan penduduk pendatang, 4) permasalahan data kependudukan. Penelitian ini tidak mencari penyebab tersebut, akan tetapi peningkatan tersebut memunculkan 
hipotesa adanya kemungkinan kantong permukiman baru bagi pendatang, jika diasumsikan bahwa dugaan penyebab penambahan penduduk beragama Islam adalah karena faktor pendatang.

Data KDA 2016 digunakan dalam pendugaan permukiman penduduk berdasarkan agama yang dianut. Pada Gambar 1 dapat dilihat bahwa terdapat kecenderungan bahwa pola permukiman dengan ciri khas agama/kepercayan cenderung mengelompok dan memusat di sekitar daerah pusat pemerintahan. Demikian pula pola sebarannya akan mengarah dari pusat ke arah luar, dengan kata lain adalah menyebar dari pusat pemerintahan.

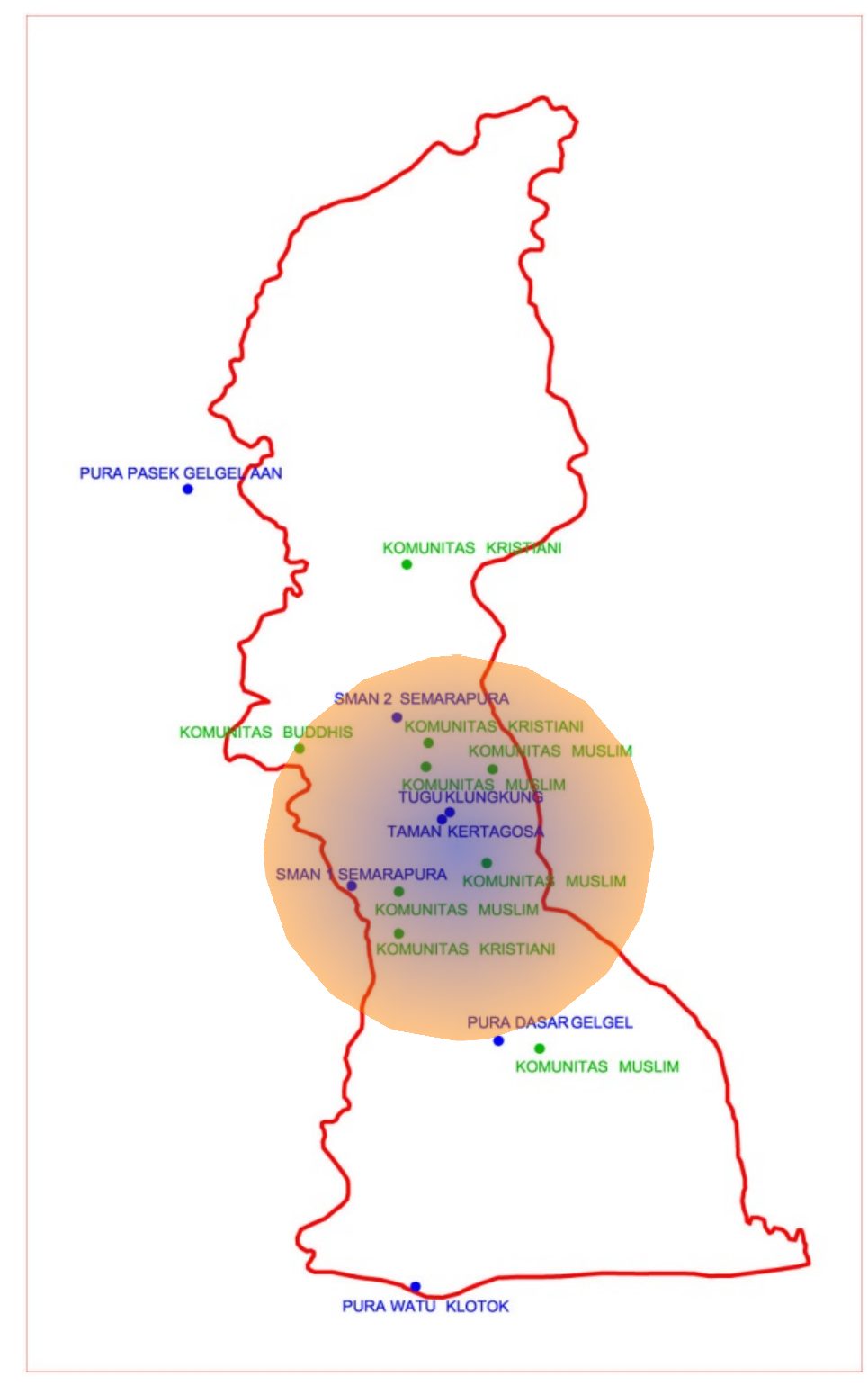

Gambar 1. Peta Sebaran Permukiman Menurut Agama/Kepercayaan

Sementara di Kecamatan Klungkung sendiri diketahui bahwa sejak jaman kerajaan dahulu terdapat satu kampung islam yang kha, yaitu Kampus Gelgel (saat ini secara administrasi disebut Desa Kampung Gelgel). Pada masa itu, Kampung Gelgel juga terletak di dekat pusat kekuasaan, yaitu Puri Kerajaan Gelgel. Bila ditelusuri lebih lanjut, maka komunitas ini dulu ada di dekat pusat kerajaan Gegel pada jaman dahulu. Soenaryo (2011) memperkirakan masuknya warga Islam pertama di Klungkung terjadi pada abad XIV, saat pemerintahan Dalem Ketut Ngulesir yang berpusat di Gelgel. Hal ini memiliki kemiripan dengan kasus Pecinan 
di kota Semarang. Pratiwo (2010) dalam penelitiannya menemukan bahwa perkembangan Pecinan di kota Semarang telah menunjukkan adanya perubahan pola permukiman dan bahkan pemindahan permukiman karena alasan politis. Peristiwa ini terjadi dalam rentang waktu sekitar 50-an tahun (antara awal abad ke-17 hingga pertengahan abad ke-17). Salah satu faktor yang menyebabkan hal tersebut adalah sistem pemerintahan yang diterapkan penjajah Belanda saat itu memang menganut pembagian kelompok berdasarkan etnis. Pada masa tersebut, selain permukiman Cina, terdapat pula permukiman untuk pribumi dan permukiman untuk Belanda dan bangsa Eropa lain. Praktik-praktik segregasi permukiman karena alas an politis jamak terjadi di masa lampau (era kolonialisme).

Pemetaan berdasarkan data sensus menunjukkan bahwa permukiman penduduk yang menganut agama tertentu cenderung masih mengelompok. Kecenderungan lain dari permukiman dengan unsur agama/kepercayaan yang tidak dominan adalah adanya tendensi letak permukiman yang mengarah lokasinya berada disekitar wilayah pusat kekuasaan. Sebaran permukiman tersebut tampaknya selaras dengan lokasi berdirinya tempat ibadah yang masih berada dalam wilayah sekitar pusat pemerintahan kabupaten Klungkung (Gambar 2). Lokasi tempat-tempat ibadah menunjukkan pola yang selaras dengan penyebaran pola permukiman berdasarkan unsur agama.

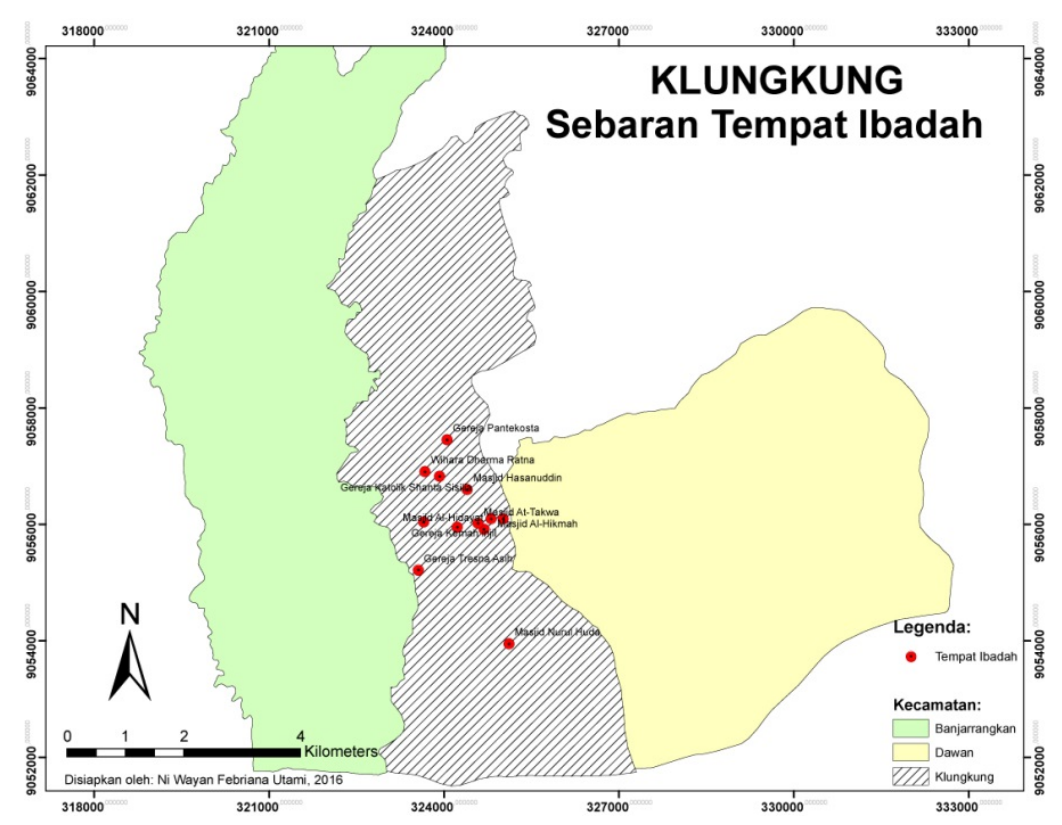

Gambar 2. Peta Sebaran Tempat Ibadah

\subsection{Profesi dan Pekerjaan Khas}

Kecamatan Klungkung terkenal atau identik dengan kuliner serombotan, lukisan Kamasan, kerajinan Pis Bolong (uang logam dengan lubang persegi di tengah), kerajinan logam alat upacara, dan juga kain tenun Endek. Produk-produk tersebut banyak dihasilkan oleh penduduk Klungkung dan juga sentra produksi yang masih berada di wilayah Kabupaten Klungkung. Pembahasan ini hanya akan melihat secara garis besar profesi penduduk berdasarkan data sensus yang mencatat industri yang berkembang di Kecamatan Klungkung. Data yang diambil hanya yang menyangkut industri kecil dengan jumlah pekerja berkisar 5 - 19 orang. Industri rumah tangga tidak dipergunakan karena pertimbangan bahwa data sensus menunjukkan sebaran industri tersebut yang ada di seluruh desa dan kelurahan yang ada di Kecamatan Klungkung. Sementara profesi atau pekerjaan khas yang diperhatikan adalah industri tekstil, karena berkorelasi dengan produksi kain Endek, dan industri barang dari logam karena diasumsikan berkaitan dengan produsen pis bolong dan produsen alat-alat upacara. 
Penterjemahan data kedalam peta menunjukkan bahwa sentra-sentra produsen tersebut cukup menyebar (Gambar 3), walaupun masih menunjukkan kecenderungan adanya korelasi dengan pusat pemerintahan.

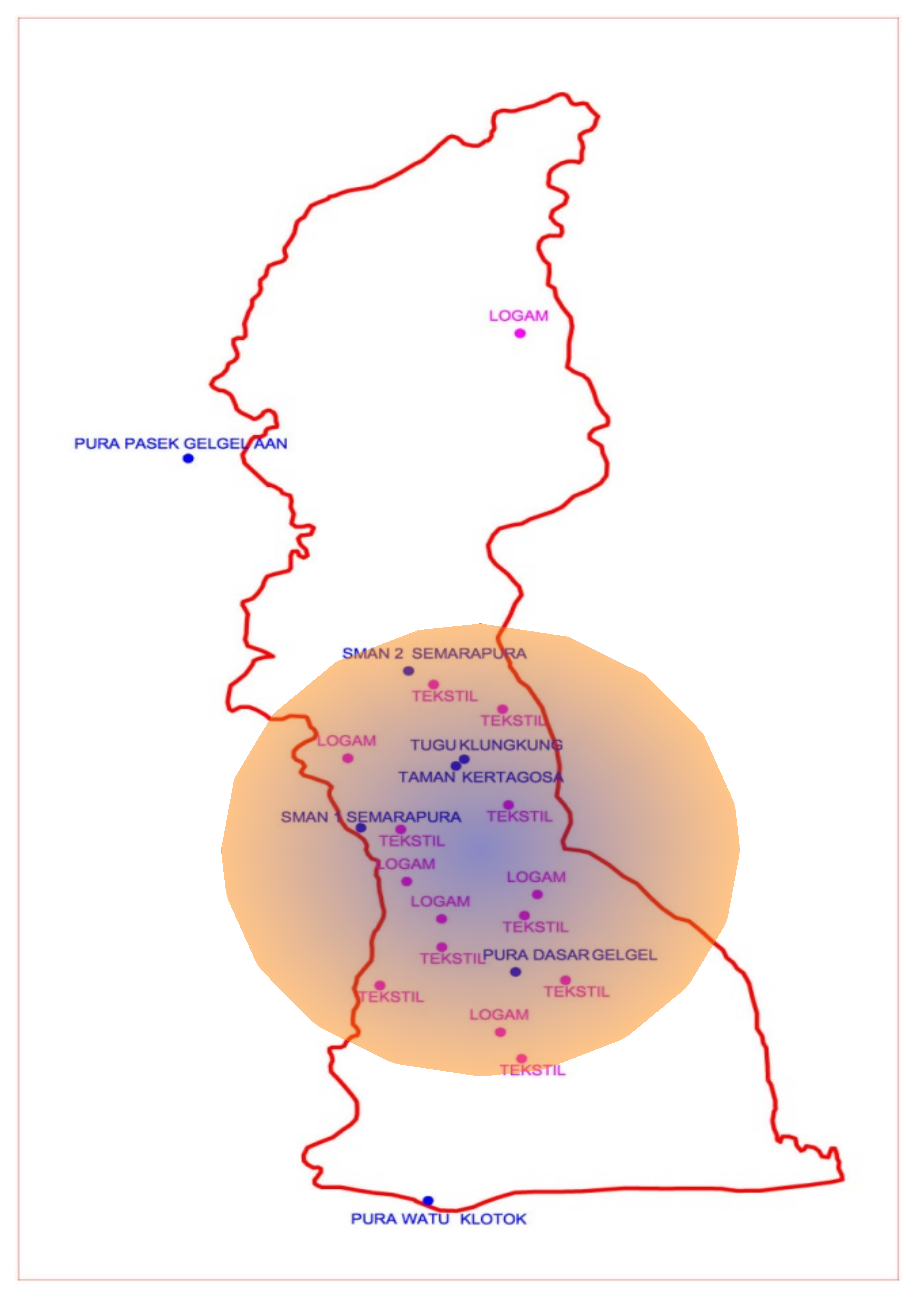

Gambar 3. Sebaran Permukiman Menurut Profesi dan Pekerjaan Khas

Namun dapat dikatakan tidak terlihat adanya indikasi pemusatan dan tidak terkait dengan permukiman tertentu. Sebaran profesi atau pekerjaan yang spesifik tersebut cukup melebar dibanding dengan karakter permukiman yang cenderung memusat. Tampaknya sebaran profesi tersebut lebih terkait dengan pertimbangan hal-hal yang bersifat ekonomi seperti pusat perekonomian. Pola permukiman berdasarkan pekerjaan yang terlihat relatif cukup acak. Diperkirakan faktor ekonomi dan globalisasi memiliki pengaruh yang lebih besar dari segi perkembangan pola permukiman di Kecamatan Klungkung. Hal ini sejalan dengan pandangan yang dikemukakan oleh Irwan Abdullah (2008) menyatakan bahwa proses globalisasi terjadi dalam tiga tahap perubahan, yaitu tahap satu yang ditandai dengan masuknya pasar ke dalam masyarakat petani, tahap kedua ditandai dengan integrasi pasar, dan tahap ketiga sebagai ekspansi pasar. Salah satu akibat yang disimpulkan Abdullah dari perubahan tahap ketiga adalah terjadinya pemindahan batas dan ikatan tradisional mengikuti logika berpikir pasar. Secara material diindikasikan munculnya pola-pola organisasi ruang dan identifikasi diri yang berbeda. Kasus kecamatan Klungkung tampaknya dapat dikatakan mengalami perkembangan sesuai dengan pola organisasi ruang yang lebih cenderung mengikuti logika berpikir pasar. 


\subsection{Etnis/Suku/Ras}

Data sensus dari profil KDA 2016 tidak menunjukkan adanya sensus yang terkait dengan etnis/suku/ras. Demikian juga dengan KDA dari tahun 2011 hingga tahun 2015 tidak memperlihatkan ada pencatatan penduduk berdasarkan aspek tersebut. Tidak adanya data atau catatan mengenai aspek tersebut mengindikasikan kemungkinan unsur tersebut tidak signifikan bagi Kecamatan Klungkung. Demikian pula dapat diasumsikan adanya karakter kependudukan yang homogen dikalangan masyarakat Klungkung. Responden usia dewasa muda (16 - 18 tahun) mengalami kesulitan untuk memetakan komunitas yang diindikasikan berdasarkan etnis/suku/ras di kecamatan Klungkung.

Temuan penyekatan berdasarkan etnisitas atau suku tampaknya tidak nyata di kalangan generasi muda di wilayah kecamatan Klungkung. Hal ini berseberangan dengan teori umum bahwa identitas personal terkait dengan kebudayaan melekat pada pribadi orang yang bersangkutan akan mencirikan ruang geografis berdasarkan pengalaman lanskap. Salah satu yang mengemukan teori tersebut adalah Tilley (1994), yang mengatakan bahwa identitas personal dan kebudayaan menyatu dengan suatu tempat. Fenomena yang terjadi lebih sesuai apabila dijelaskan dengan teori globalisasi yang pada dasawarsa terakhir mengemuka. Globalisasi budaya menurut King (2004) telah mnyebabkan difusi informasi, tampilan rupa, budaya profesi, dan bahkan sub-sub budaya seperti arsitektur, perencanaan desain urban, konservasi yang keseluruhannya didukung oleh aliran capital internasional. Akibatnya dalah perubahan-perubahan maupun gerakan-gerakan yang terjadi bersifat lebih liberal. Lash dan Urry (dalam King, 2004) melihat bahwa perubahan yang terjadi sebagai akibat 'deteritorialisasi' sebagaimana istilah yang dipakai oleh Appadurai.

\section{Simpulan}

Pola permukiman apabila ditinjau dari unsur agama/kepercayaan menunjukkan model permukiman yang cenderung mengelompok. Pengelompokan dimulai dari titik pusat mengarah ke luar. Fenomena ini terutama tampak pada komunitas agama yang tidak dominan (Islam, Budha, Kristen/Katolik) yang cenderungan berada dan mengumpul sekitar pusat pemerintahan. Indikasi mengelompok dalam hal agama/kepercayaan untuk kasus di kecamatan Klungkung dapat dipakai sebagai data untuk pembuatan kebijakan terkait kerukunan beragama dan aspek-aspek sosial terkait pluralitas bernegara di NKRI.

Sementara pola yang berorientasi pusat tidak tampak apabila dianalisa dari unsur profesi/pengrajin. Pola yang terbentuk cenderung menunjukkan sebaran yang melebar. Sebaran unsur profesi yg spesifik cenderung lebih merata. Unsur profesi tidak menunjukkan keterkaitan khusus dengan pemerintahan namun berkait dengan pusat ekonomi. Temuan ini dapat dipakai sebagai data untuk pengembangan sentra ekonomi, khususnya UMKM di wilayah kecamatan Klungkung.

\section{Ucapan Terima Kasih}

Penulis mengucapkan terima kasih kepada Fakultas Pertanian Universitas Udayana dan LPPM Universitas Udayana yang telah menyetujui untuk mendanai penelitian ini. Penelitian dibiayai DIPA PNBP Universitas Udayana sesuai dengan Surat Perjanjian Penugasan Pelaksanaan Penelitian, Nomor Kontrak: 1267/UN14.1.23/PL/2016, tanggal 15 Juni 2016.

\section{Daftar Pustaka}

Abdullah, Irwan. 2008. Titik Balik Peradaban dan Kebangkitan Budaya Baru. Makalah disampaikan pada Sarasehan Pesta Kesenian Bali (PKB) XXX.

Kecamatan Klungkung Dalam Angka. 2016. Badan Pusat Statistik Kabupaten Klungkung.

King, Anthony D. 2004. Spaces of Global Cultures: Architecture Urbanism Identity. Routledge, New York. Kecamatan Klungkung Dalam Angka. 2016. Badan Pusat Statistik Kabupaten Klungkung. Pratiwo. 2010. Arsitektur Tradisionall Tionghoa dan Perkembangan Kota. Penerbit Ombak, Yogyakarta. Tilley, C. 1994. A Phenomenology of Landscape - Places, Paths and Monuments. Berg Publishers, OxfordUK. Undang-Undang Republik Indonesia Nomor 1 Tahun 2011 tentang Perumahan dan Kawasan Permukiman 